\title{
コンクリートの乾燥収縮の内部機構に関する一考察*
}

\author{
西林 新蔵** 阪田憲 次**
}

\section{A Study on the Shrinkage Mechanism of Concrete}

\author{
by
}

\author{
Shinzo Nishibayashi and Kenji Sakata \\ (Faculty of Engineering, Tottori University, Tottori)
}

Though various studies on the shrinkage of concrete have been made by many researchers, most of them have not dealt with its mechanism. In order to explain the shrinkage mechanism of concrete, the shrinkage test and water loss test were performed in this study on three different concretes (a crushed stone concrete and two lightweight aggregate concretes). From the test results, the relationship between shrinkage strain and water loss as well as the effect of ambient humidity on shrinkage and water loss were discussed.

The results of this study can be summarized as follows :

(1) The water loss of concrete by drying increases with increasing water content in concrete and with decreasing relative humidity in the atmosphere.

(2) When the ambient humidity is low, it is suggested that the mechanism of water loss may be divided into two processes.

(3) The shrinkage strain decreases with increasing ambient humidity.

(4) It is suggested that the shrinkage mechanism of concrete may be divided into two processes. In the first process, the water loss from the aggregate or capillary pore is so dominant that the shrinkage accompanied with the water loss increases slowly. In the second process, the water loss from the gel pore becomes significant and subsequently the shrinkage increases rapidly.

(5) The shrinkage of concrete is roughly proportional to the water loss. However, the proportional constant varies depending upon the kind of concrete.

(Received Sep. 9, 1972)

\section{1 緒言}

コンクリートの乾燥収縮は, クリープと同様にコン クリートが有する重要な性質の一つであり, 従来より 内外の多くの研究者によって種々の面より検討されて きた。とくにPC 構造物の設計に拈いては, 乾燥収縮 やクリープによるプレストレスの減退が問題になる. さらに, 最近の構造物の長大化, 巨大化に伴い, 構造 物の軽量化が要請される結果, 人工軽量骨材コンクリ ートと普通コンクリートおよび鋼の合成断面を有する 構造物が登場し, この種の構造物においては打ち継ぎ 部に発生する収縮差応力が設計上重要な問題となって いる．また，収縮によるひびわれは鉄筋の錆化をもた らし, 鉄筋コンクリートの海洋構造物への適用に拈い ては看過でさない問題の一つでもある.このように, 多種多様な形式のコンクリート構造物の出現と, その 構造物が施工される環境範囲の拡大に伴い, この種の 問題の重要性が改めて認識されるべき現状にあると思

* 原稿受理 昭和 47 年 9 月 9 日

** 正会員 鳥取大学工学部 鳥取市湖山町
われる。

コンクリートの乾燥収縮におよぼす諸要因の影響に ついては, 従来の研究においてもかなり詳しく検討さ れている.しかし, 実際の構造物の設計に際しては, 乾燥収縮の量を正しく予知することが必要となる。そ のためには, 種々の条件下における乾燥収縮のデータ の蓄積ばかりでなく、コンクリートの乾燥収縮をその 内部機構の面からも検討を加えることはきわめて重要 な問題であると思われる. 従来の研究によれば, コン クリートの乾燥収縮の内部機構は, 供試体と環境との 湿度こら配に起因するシーページ効果によって定性的 に説明されているものが多く，それを定量的に明らか にしたものはきわめて少ないよらである。

本研究は，コンクリートの乾燥収縮を論じる場合の 重要な要因の一つであるコンクリート中の水分の挙動 に着目し, 吸水量の異なる 2 種類の人工軽量骨材およ び天然骨材を用いたコンクリートの乾燥収縮試験を実 施し, 逸散水量と収縮ひずみとの関係, ならびに乾燥 収縮に扣よぼす環境の湿度条件の影響について検討し 
たものである.さらに, これらの結果をもとにして乾 燥収縮の内部機構について若干の考察を行なったもの である。

\section{2 実 験 概 要}

本実験に使用した骨材（天然骨材； $N$ ，ライオナイ ト；Lおよび宇部軽骨；U）の物理的性質を Table I に示す。セメントは, 大阪社製普通ポルトランドセメ ントを用いた．本実験に用いたコンクリートの配合を Table II に示す．本実験に捛いては目標強度は考慮 せず，セメント，水，細骨材拉よび粗骨材の容積率が コンクリートの種類にかかわらず一定となるよらに考 慮した。

Table I. The physical properties of aggregates used in this test.

\begin{tabular}{|c|c|c|c|c|c|}
\hline \multicolumn{2}{|c|}{$\begin{array}{l}\text { Kinds of } \\
\text { aggregate }\end{array}$} & $\begin{array}{l}\text { Specific } \\
\text { gravity }\end{array}$ & $\begin{array}{l}\text { Water } \\
\text { absorption } \\
(\%)\end{array}$ & $\begin{array}{l}\text { Weight of } \\
\text { unit vol. } \\
\left(\mathrm{kg} / \mathrm{m}^{3}\right)\end{array}$ & $\begin{array}{c}\text { Fineness } \\
\text { modulus } \\
\text { F.M. }\end{array}$ \\
\hline \multirow{3}{*}{$\begin{array}{l}\dot{0} \\
0 \\
0 \\
0 \\
0 \\
5 \\
8 \\
\delta\end{array}$} & $\begin{array}{l}\text { Crushed } \\
\text { stone }\end{array}$ & 2.70 & 1.21 & 1530 & 7.29 \\
\hline & Lionite & 1.34 & 2.30 & 800 & 6.65 \\
\hline & $\begin{array}{l}\text { Ube- } \\
\text { keikotsu }\end{array}$ & 1.57 & 13.0 & 843 & 6.51 \\
\hline \multirow{3}{*}{ 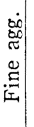 } & River sand & 2.56 & 1.23 & 1420 & 2.98 \\
\hline & Lionite & 1.37 & 4.00 & 1100 & 2.62 \\
\hline & $\begin{array}{l}\text { Ube- } \\
\text { keikotsu }\end{array}$ & 1.90 & 11.5 & 1120 & 2.53 \\
\hline
\end{tabular}

Table II. Mix proportions.

\begin{tabular}{|c|c|c|c|c|c|c|c|}
\hline Specimen & $\begin{array}{l}W / C \\
(\%)\end{array}$ & $\mid \begin{array}{c}\mathrm{C} \\
(\mathrm{kg} / \\
\left.\mathrm{m}^{3}\right)\end{array}$ & $\begin{array}{c}W \\
(\mathrm{~kg} / \\
\left.\mathrm{m}^{3}\right)\end{array}$ & $\begin{array}{l}S / a \\
(\%)\end{array}$ & \begin{tabular}{c|}
$\mathrm{S}$ \\
$(\mathrm{kg} /$ \\
$\left.\mathrm{m}^{3}\right)$
\end{tabular} & $\begin{array}{c}\mathrm{G} \\
(\mathrm{kg} / \\
\left.\mathrm{m}^{3}\right)\end{array}$ & $\begin{array}{l}\text { Pozz. } \\
\text { No. } 8 \\
\end{array}$ \\
\hline $\begin{array}{l}\text { Crushed } \\
\text { stone }\end{array}$ & 45 & 360 & 162 & 45 & 823 & 1045 & 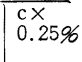 \\
\hline Lionite & " & $"$ & " & " & 548 & 518 & " \\
\hline $\begin{array}{l}\text { Ube- } \\
\text { keikotsu }\end{array}$ & " & " & " & " & 601 & 607 & " \\
\hline
\end{tabular}

乾燥収縮および逸散水量測定用の供試体は，すべて $10 \times 10 \times 40 \mathrm{~cm}$ の角柱供試体である.

コンクリートの練り混ぜは， 4 切可傾式ミキサーで 行ない, 供試体の締固めは棒突き法によった。供試体 は打設後24時間実験室中 (室温)に放置した後脱型し， 脱型後は材令28日目まで標準水中養生を施した。

乾燥収縮ひずみおよよ゙逸散水量の測定は材令28日か ら開始し, 約 100 日間測定を継続した。ひずみの測定 はフーゲンベルガー型ひずみ計（検長 10 インチ）, 逸 散水量の測定は卓上台科（科量 ; $10 \mathrm{~kg}$, 感量 $1 \mathrm{~g}$ ) を 用いて行なった。

Table III にその他の実験条件を示す. Table 中の $S$ は, 供試体の表面を防水性のビニール塗料で被覆し たもの, US は被覆しないものを意味し, 水中の供試 体についてはUSのみとした.な拈, 水中に保存した 供試体においては, 水分の逸散はないものと仮定して, 逸散水量の測定は行なわなかった。
Table III. Designations of curing conditions.

\begin{tabular}{|c|c|c|c|}
\hline Specimen & Temperature & $\begin{array}{l}\text { Relative } \\
\text { humidity }\end{array}$ & $\begin{array}{l}\text { Surface } \\
\text { treatment }\end{array}$ \\
\hline Crushed stone & & $50 \% \quad(L)$ & Sealed $(S)$ \\
\hline Lionite & $20^{\circ} \mathrm{C}$ & $80 \% \quad(H)$ & \\
\hline Ube-keikotsu & & $\begin{array}{r}100 \%(W) \\
\text { (in water) }\end{array}$ & $\begin{array}{l}\text { Unsealed } \\
\qquad(U S)\end{array}$ \\
\hline
\end{tabular}

\section{3 実験結果と考察}

乾燥収縮ひずみ拈よび逸散水量の測定結果をTable IV に示す。な乾燥収縮および逸散水量は，いずれ も試験開始後 100 日目の測定值 $\left(S_{100}, W_{100}\right)$ である. Fig. 1 は表面を塗料で被覆しない供試体の乾燥収縮と 時間の関係を示したものである.

従来の研究によれば, 軽量コンクリートの乾燥収縮 は普通コンクリートのそれと同程度か, あるいは若干 大きくなるとするものが多い。しかしながら本実験の 結果によれば, ライオナイトを用いたコンクリートの 乾燥収縮は普通コンクリートのそれと大差はないが， 吸水量の大きい宇部軽骨を用いたコンクリートの乾燥 収縮は, 普通コンクリートのそれに比較してかなり小 さい。これは骨材中の遊離水がセメントペースト部へ 補給され，その結果セメントペーストの収縮が妨げら

Table IV. Test results.

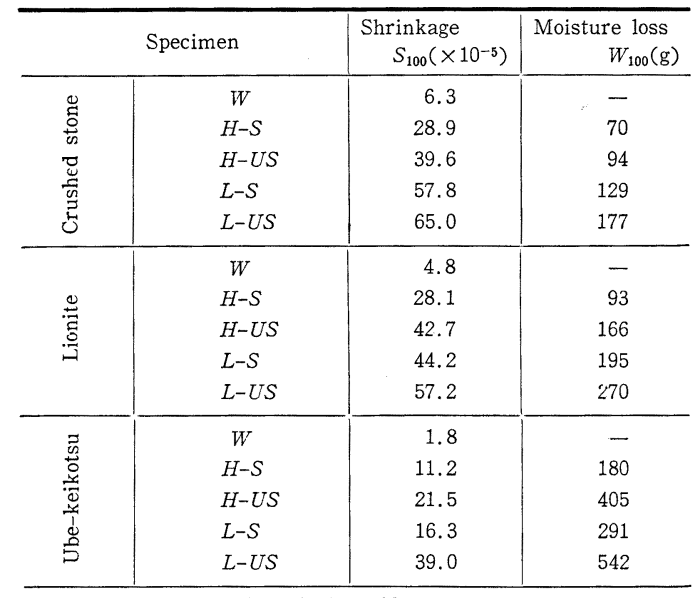

$W_{100}$; Moisture loss during 100 days

$S_{100}$; Shrinkage strain during 100 days

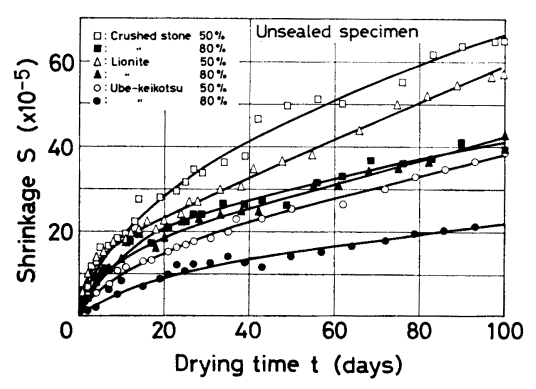

Fig. 1. Shrinkage vs. drying time curves. 
れるためであると予想される。

一方, Table IV によれば, 一般に表面を被覆した 供試体の乾燥収縮は, 被覆しない供試体のそれよりも 小さい。これは, 表面を被覆することによって供試体 中の水分が外部へ逸散するのが妨げられるため，その 乾燥収縮が小さくなったものと考えられる.さらに Fig. 1 によれば, 環境の湿度が高いほどその乾燥収縮 は小さくなる、これは，環境の湿度が高くなれば供試 体中の水分の逸散は緩慢となり, その結果乾燥収縮が 小さくなるためである. Fig. 2 に環境の湿度と乾燥収 縮の関係を一括して示した.これによれば,コンクリ 一トの種類にかかわらず, 環境の湿度が高いほどその 乾燥収縮が小さく, さらに表面を被覆して水分の逸散 を少なくしたもの汪ど，その乾燥収縮が小さくなるこ とが明確にわかる。

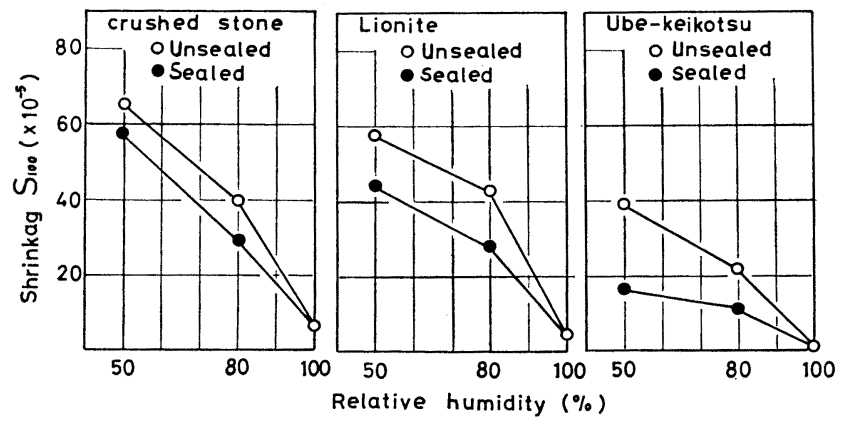

Fig. 2. Influence of ambient humidity on shrinkage.

以上述べたように，コンクリートの乾燥収縮は供試 体中の水分の外部への逸散に起因するところが大きく， 供試体中の水分の多寡, 環境の湿度条件および表面の 被覆の有無などの要因が支配的であると考劣られる。 したがって、コンクリートの乾燥収縮の内部機構を論 じる際には，コンクリート中の水分の挙動に着目すべ きであることには異論がないものと思われる。

Fig. 3 は表面を被覆しない供試体の水分の逸散と時 間の関係を示したものである.Fig. 3 によれば，供試 体中の水分が多くなるにしたがって，さらに環境の湿 度が低い汪ど，その逸散水量は多くなる。

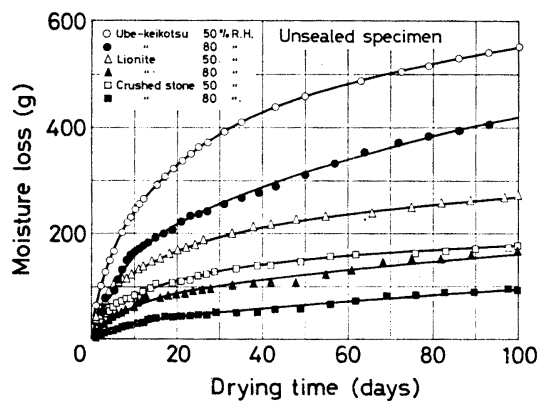

Fig. 3. Moisture loss vs. drying time curves.
Table V. Moisture loss during 100 days after the start of the drying test.

\begin{tabular}{|c|c|c|c|}
\hline \multicolumn{2}{|c|}{ Specimen } & $W_{T}(\mathrm{~g})$ & $W_{100} / W_{T}(\%)$ \\
\hline 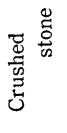 & $\begin{array}{l}H-S \\
H-U S \\
L-S \\
L-U S\end{array}$ & 407.9 & $\begin{array}{l}17.2 \\
23.0 \\
31.6 \\
43.4\end{array}$ \\
\hline 䓌 & $\begin{array}{l}H-S \\
H-U S \\
L-S \\
L-U S\end{array}$ & 452.2 & $\begin{array}{l}22.1 \\
36.7 \\
43.1 \\
59.7\end{array}$ \\
\hline 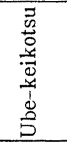 & $\begin{array}{l}H-S \\
H-U S \\
L-S \\
L-U S\end{array}$ & 908.9 & $\begin{array}{l}19.8 \\
44.6 \\
32.0 \\
59.6\end{array}$ \\
\hline
\end{tabular}

$W_{T}$; Total amount of water contents

$W_{100}$; Moisture loss during 100 days

一方, 供試体の乾燥に伴って逸散し得る 水量は, 供試体の有する全水量より結合水 を引いたものと考えられる・いま, 結合水 をセメント重量の $23 \%$ と仮定して逸散し得 る水量 $\left(W_{T}\right)$ を求めると, 普通コンクリー トで $407.9 \mathrm{~g}$, ライオナイトで $452.2 \mathrm{~g}$, 宇 部軽骨で $908.9 \mathrm{~g}$ となる.さらに, $W_{T}$ に 対する $W_{100}$ の割合を求めると Table V の ようになり, 軽量コンクリートに比較して 普通コンクリートのそれは若干小さいよう である。

Fig. 4，5 は，表面を被覆しない供試体の逸散水量 と単位時間（日）当たりの逸散水量（逸散速度）との 関係を示したものである.Fig. 4 によれば，環境の湿 度が低い場合には，いずれのコンクリートに拈いても 両者の関係は折線で表わされ，逸散水量がある值を越 えると逸散速度は急激に低下する。このことより，コ

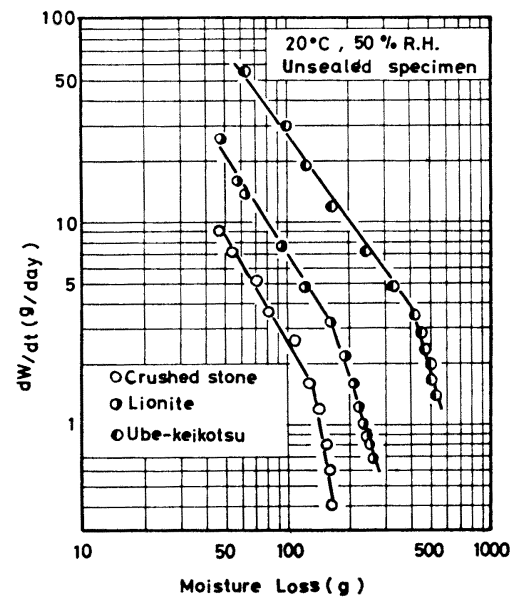

Fig. 4. Relationship between moisture loss and rate of moisture loss (at 50\% R.H.). 


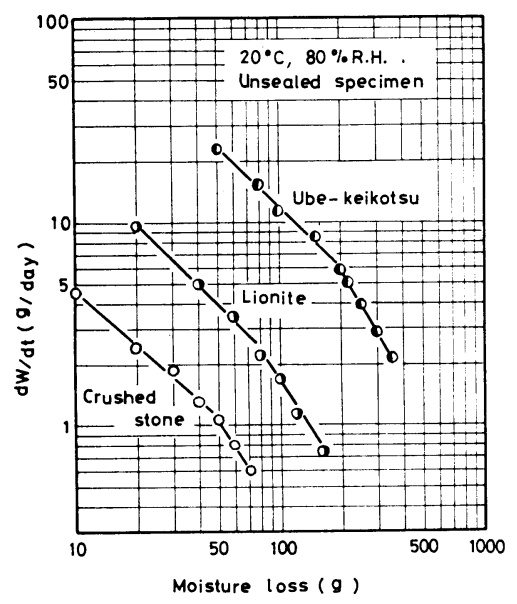

Fig. 5. Relationship between moisture loss and rate of moisture loss (at $80 \%$ R. H.).

ンクリート中の水分の逸散の機構は一様なものではな く，ある時間を境にして何らかの相違のあることが想 像される. Fig. 5 は環境の湿度が高い場合について示 したものであるが，こて場合も Fig. 4 と同様の傾向が 認められる。しかしながら，一般に逸散速度は環境の 湿度が低い場合よりも小さく, 逸散の機構の变化もそ れほど顕著なものではない。

Fig. 6, 7 は表面を被覆しない供試体の乾燥収縮ひ ずみと逸散水量の関係を示したものである. Fig. 6 よ り明らかなよらに，環境の湿度が低い場合には，コン クリートの種類にかかわらず乾燥収縮ひずみは逸散水 量の増大に伴って直線的に増加し，ある值を過ぎると その直線のこう配は大きくなる。すなわち, 両者の関 係は一つの折線で表わされる。また，直線のこう配は

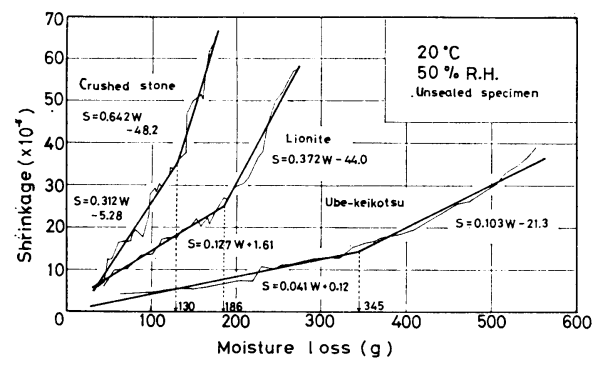

Fig. 6. Relationship between shrinkage and moisture loss (at 50\% R.H.).

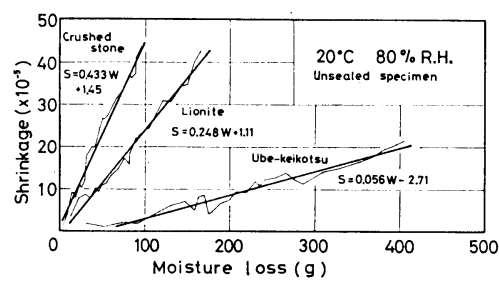

Fig. 7. Relationship between shrinkage and moisture loss (at $80 \%$ R.H.).
コンクリート中の水量が多くなるにしたがって小さく なっている。

一方，コンクリート中の水はその存在形態によって 化学的結合水, セメントゲル中のゲル水, 毛細管空げ き中のキャピラリー水执よび骨材中の水の 4 種類に分 類される. これらのうち化学的結合水は先にも述べた ように, 乾燥に伴って供試体外へ逸散することはない と考えられる. また, キャピラリ一水や骨材中の水は 乾燥収縮にそれほど多大な影響を及ぼさないと思われ る、したがって, 乾燥収縮の原因はセメントゲル中に 拘束されて存在するゲル水の逸散によるところが大で あると考えられる。

Hobbs と Mears ${ }^{3)}$ は，コンクリートの内部機構 と 水分の逸散との関係について次のように述べている. すなわち, コンクリートは互いに連絡された種々の大 きさの空げきを有し，このようなコンクリートが乾燥 されると，メニスカスを形成している大きな毛細管空 げき中の水は表面から蒸発し, 水分は徐々に外部へ逸 散する. 水分の蒸発によってメニスカスの曲率が増大 し，それに伴って生じた張力によって，骨材中やセメ ントペースト中の大きな空げきの中の自由水が, 水分 を失なった毛細管空げきへ移動する。このような過程 を繰返しつつ乾燥が進行すると, コンクリートの表面 に近い内部の湿度は充分に低くなり, その結果すでに 水分を失なった比較的大きな空げきの壁面やメニスカ スが表面から後退することによって, 露出してきたゲ ル空げきなどからも水分が失われるよらになる．さら に乾燥が進行すると, 比較的大きな毛細管空げきのメ ニスカスは失われ, 水分の逸散はコンクリート表面と 内部との湿度こう配にのみ起因するようになる。ささ に乾燥が進行すると，コンクリート中の湿度はさらに 低くなり，炭酸化による重量増大が認められるように なる・

以上の考えを参考にして本実験の結果を考察すると 次のようになる.すなわち，Fig. 6 に示した本実験の 結果のみからは, Hobbs と Mears が述べるように, 乾燥収縮の内部機構を微視的に, 厳密に区別すること は困難ではあるが，コンクリートの乾燥収縮は二つの 違った機構によることがわかる.それはFig. 6 におい て折線で表わされているよらに, 最初の段階に扣いて は骨材中の水や毛細管空げき中の水の逸散が支配的で あり，水分の逸散が多いにもかかわらず乾燥収縮ひず みはそれほど増大しない，次の段階になればゲル空げ き中の水の逸散が支配的となり, 乾燥収縮ひずみの増 加の割合は大となる。したがって, 骨材中に有する水 量の多い宇部軽骨を用いたコンクリートにおいては, 逸散水量が多いにもかかわらず，その乾燥収縮は小さ くなっている。 
Fig. 6 に乾燥収縮の内部機構が変化する点に括ける 逸散水量の值を示したが，これはFig. 4 に示した水分 逸散の機構が変化する点の逸散水量の值とほぼ一致す る. このことからもコンクリートの乾燥収縮の内部機 構がコンクリート中の種々の形態の水の逸散の機構之 密接に関係することが明らかである。また，乾燥収縮 の内部機構が変化する点の逸散水量は, コンクリート が有する結合水以外の水量の約 $30 \sim 40 \%$ である.さら にこの点に達するのに要する日数は, 環境の湿度が50 \%の場合に拈いては, 普通コンクリート, ライオナイ トおよび宇部軽骨で，それぞれ30日，28日および23日 となり，ほぼ20～30日程度である。

Fig. 7 には環境の湿度が高い場合について示したが, 湿度が高く水分の逸散が妨げられた結果, 逸散水量も 少なく, 内部機構の変化をみるに至らず, 乾燥収縮ひ ずみと逸散水量との間にはほ注線的な関係がみられ た、また，コンクリートが有する水量が多くなるにし たがって直線のこら配が小さくなることはFig. 6 の場 合と同様である。なお, 表面を被覆した供試体の結果 については, 紙面の関係上割愛するが, 表面を被覆し ない供試体の場合とほぼ同様の傾向がみられた。

Fig. 8 は測定開始後 100 日目に括ける乾燥収縮と逸 散水量の関係を示したものであるが，コンクリートの 種類にかかわらず両者の関係はほ租線で近似するこ とができる、すなわち、コンクリートの乾燥収縮は, 巨視的にみれば，供試体中の水分の逸散水量と此例す るといえる，また，その直線のこら配は，コンクリー

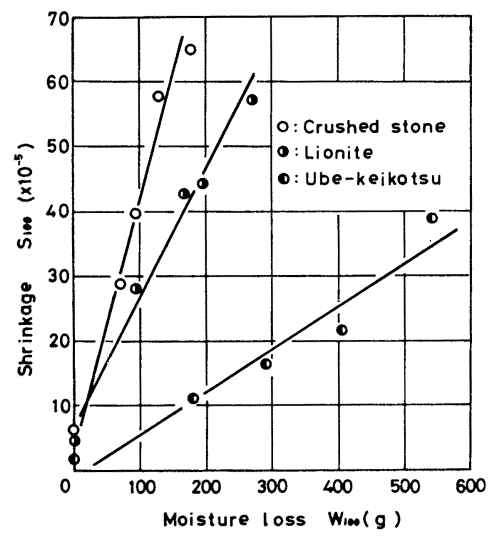

Fig. 8. Relationship between shrinkage $S_{100}$ and moisture loss $W_{10}$.
トが有する水分の量と密接な関係があり，水分の量が 多いほどゆるやかになる。

\section{4 結言}

本研究の結果明らかになったことを列挙して結論と する。

（1）コンクリートの乾燥に伴う水分の逸散は，コン クリートが有する水量, 環境の湿度条件および表面の 被覆の有無などと密接な関係を有する.すなわち、コ ンクリートが有する水量が多いほど，環境の湿度が低 いほど，さらに表面を被覆しないものの方が逸散水量 は大となる。

（2）環境の湿度が低い場合，コンクリート中の水分 の逸散は二つ異なった機構からなると思われる。

（3）コンクリートの乾燥収縮におよぼす環境の湿度 条件の影響は大きく, 湿度が高くなれば乾燥収縮は小 さくなる，また，表面を被覆したコンクリートの乾燥 収縮は，被覆しないもののそれよりも小さい。

（4）コンクリートの乾燥収縮の内部機構は, 二つの 異なった機構からなると考えられる。すなわら, 骨材 中の水分や毛細管空げき中の水の逸散が支配的である ため, 水分の逸散に伴う乾燥収縮ひずみの増加が比較 的ゆるやかな段階が先行し，次にゲル空げき中の水の 逸散が支配的となって，水分の逸散に伴う乾燥収縮ひ ずみの増加が急になる段階が続く。

（5）コンクリートの乾燥収縮を巨視的にみれば，乾 燥収縮は逸散水量とほぼ比例する。また，それはコン クリートが有する水量と密接な関係がある.

本研究を遂行するに当たり，多大の労を煩わした斎 藤邦雄（空港コンサルタントK. K. ），手嶋良三（愛 知県) の両氏に対し, 心から感謝の意を表する.

\section{参考文 献}

1) Neville, A.M., Properties of Concrete, Sir Isaac Pitman \& Sons Ltd. (1968).

2) 岡田 清, コンクリートのクリープ, コンクリートパン フレット第29号，日本七メント技術協会.

3) Hobbs, D.W., and A.R. Mears, The Influence of Specimen Geometry upon Weight Change and Shrinkage of Air-Dried Mortar Specimen, Magazine of Concrete Research, 23, No. $75 \sim 76$, June-September, (1971). 